explains the underlying educational theories and models concerning learner development. With a better understanding of areas of student affairs, librarians can clearly make a larger impact in such areas as citizenship, assessment, and career services. These chapters also uncover the big picture and the relevance of partnerships between librarians and student affairs: education and development as a whole. Following these two chapters are thirteen case studies that concisely describe various collaborative scenarios between the libraries and student affairs: promoting collaboration, introducing programs and services, enhancing access to patrons with disabilities, creating learning commons, and more. The case studies come from institutions that vary in size and illustrate collaborations with various service points, which should satisfy the needs of librarians working in various environments. Hinchliffe and Wong conclude with "Lessons on Collaboration," in which they stress the role of environment, highlight best practices, remind us of the potential for collaboration in various situations, and provide a select bibliography for further readings on student affairs, strategies for collaboration, and partnerships between libraries and student affairs.

Hinchliffe's reputation as an information literacy expert is well established nationally and internationally. She has lectured at conferences, given workshops, and is one of several ACRL Immersion Program's faculty. The program provides librarians with intense training in various aspects of information literacy, from instruction to assessment, and prepares them to create or improve information literacy initiatives at their own academic institutions. She holds two masters' degrees in educational psychology and library and information science. Currently she is Coordinator for Information Literacy and Associate Professor of Library Administration at the University of Illinois at Urbana-Champaign. Melissa Wong is a seasoned librarian, consultant, and adjunct faculty at San Jose State University and the University of Illinois at UrbanaChampaign, where she earned her master's degree in library and information science. She has administrative experience as previous Director at Marymount College, California, and as instructor, having developed and taught information literacy courses in several universities.

Several librarians have written articles about collaboration initiatives in their institutions, as illustrated at the end of Hinchliffe and Wong's book in "Resources for Further Readings." This book is unique, however, because it serves as a cumulative reference resource for a topic that is generating increasing interest. Librarians can certainly find resources that treat collaborations and student affairs independently and even some articles bridging these two services; but, to my knowledge, this is the first resource that aggregates fundamental information for professionals interested in building such partnerships within their academic institutions by providing an overview of the professions and illustrating collaborative initiatives with case studies. Professionals in libraries or student affairs who may be considering building such partnerships will find Hinchliffe and Wong's Environments for Student Growth and Development an essential source of information. - Ethan Pullman, Carnegie Mellon University.

\section{The Library of Congress and the Center} for the Book: Historical Essays in Honor of John Y. Cole. Ed. Mary Niles Maack. Washington: Library of Congress in association with the University of Texas Press, 2011. 223p. \$24.95 (ISBN 9780844495255). LC2011-020436. Mary Niles Maack, Professor Emerita of UCLA's Department on Information Studies, has edited an admirable volume dedicated to John Y. Cole, the "foremost expert on the history of the Library of Congress," and, as the founder of the Center for the Book, a significant figure in promoting the history of the book and library history. This festschrift originated with papers delivered at a research forum 
in John Cole's honor sponsored by ALA's Library History Roundtable, which were expanded, added to, and published in a special issue of Libraries $\mathcal{E}$ the Cultural Record (volume 45, number 1, 2010). This collection also contains a new essay by Cole, "A Life at the Library of Congress," and a bibliography of his writings (1970-2010).

In "Histories of the Library of Congress," Jane Aikin, the Director of the Division of Research Programs at the NEH since 2010, touches on book-length studies and major articles, and admits that "it is impossible to even reference the numerous theses, memoirs, articles, guides, pictorial works, and exhibition catalogs" describing the great "LC." Aikin notes that many of the historians were (and are) LC staff members, and one of the more intriguing histories she mentions is an unpublished and unfinished work (but comprehensive within its scope) now located in the Manuscripts Division. "Considering the mass of documentation available to them," Aikin concludes, "historians writing during the past two decades have, perhaps wisely, confined their investigations chiefly to topical analyses or limited periods. John Cole, whose writings range across the entirety of LC history, is, of course, the exception."

Josephus Nelson, an LC staff writer/ editor (and former reference librarian), offers an account of the development of the institutional archive of the Library, which really didn't coalesce until the 1940s. Even LC was not immune to the commonplace that the least important record group in a given organization is its own archive. The Library had operated nearly a century before it began consciously preserving its records, and there was no office designated to do so until 1944, when Librarian Archibald MacLeish placed the responsibility in the Office of the Secretary. Working with the National Archives, an inventory of the records of forty-nine administrative units was conducted, and in the ensuing decades there was debate on the location and role of the archive. In 1981 it was transferred to the Manuscripts
Division, where it now resides and contains well over 3.5 million items.

"The National and International Roles of the Center for the Book" are explored by Guy Lamolinara, an LC staffer since 1990 who now serves as the Center's communications officer. He offers a brief sketch of the origins of the Center and describes the major programs initiated, publications produced, promotional themes developed, and the origins of the state centers. He then covers the international activities of the Center for the Book and discusses conferences held in other countries, as well as outlining the Center's affiliates abroad. In a thematically related historical article, Nancy E. Gwinn (Director of the Smithsonian Institution) discusses how an early partnership between the Library of Congress and the Smithsonian resulted "in an international convention for an official worldwide system of publications exchange" at the end of the nineteenth century.

A further exploration of the Center's influence on book history was conducted by Eleanor F. Shevlin and Eric N. Lindquist. Shevlin is an English professor at West Chester University of Pennsylvania, and Lindquist is a librarian at the University of Maryland who holds a PhD in British history. Beginning with a thumbnail sketch of the genesis of "book history" in the 1970s, Shevlin and Lindquist explain how Cole's appointment in 1977 as the Center's founding director placed a man "equipped with a historian's eye, a collection librarian's expertise, and an administrator's skill in collaborating with disparate groups" in an excellent position to affect the new field. Collaborating with organizations like the Rare Books and Manuscripts section (RBMS) of ALA and attracting a roster of scholars that now reads like a "who's who" of well-known book historians to its advisory board, the Center has supported conferences, symposia, and publishing projects that have been crucial to the field for decades. Jean Preer, an LIS professor at Indiana University (Indianapolis), contributes a 
nicely detailed article on the roots and formation of National Library Week in 1958, which she convincingly names as the bibliocultural antecedent to the Center for the Book.

With a nod to Cole's research interests, both Carl Ostrowski (professor of English at Middle Tennessee State University) and Michael Winship (distinguished professor of English at the University of Texas at Austin) contribute articles on Ainsworth Rand Spofford, Librarian of Congress from 1864 to 1897. Ostrowski's article focuses on Spofford's development of literary collections in the 1870 s, and the conflicts Spofford felt as one who attempted to promote a narrow literary canon (great New England authors), while required by law to collect the "annual product of the American press" - which included "popular novelists he sought to exclude from the attention of readers." Winship illuminates a narrow chapter in the publication history of Uncle Tom's Cabin, related to a copyright dispute, wherein Spofford "emerges as cool, precise, and knowledgeable, in marked contrast to the 'apparent disorder' of the collections and the 'heavy plodding' nature of his clerks."
Finally, Donald G. Davis, Jr. (professor emeritus of library history at the University of Texas at Austin) submits a succinct but intriguing view of "International Trends in Library History," which serves as a sort of capstone to the volume. The practice of library history is becoming more scholarly (and is increasingly based on primary documents) rather than merely celebratory or antiquarian. It is also becoming more professional and is more often related to cultural studies, following a "new interest in and respect for the impact on individuals and communities of social libraries, public libraries, and school libraries." However, Davis presents a difficult rhetorical question for libraries and, by implication, library historians: "Surely libraries are foundational institutions like banks, courts, and churches. When all these are changing, too, where does the library stand in a culture's priorities? If cultures can move so swiftly to the cell phone age without developing serious literacy, what does that tell us about the presumed value of collected materials called libraries?" Richard J. Ring, The Watkinson Library, Trinity College.

\section{CALL FOR NOMINATIONS}

Excellence in Academic Libraries Award

$\$ 3,000$ and a plaque

Sponsored by YBP Library Services

Academic/Research Librarian of the Year

$\$ 5,000$ and a plaque

Sponsored by YBP Library Services

\section{And Many Other Award Opportunities}

Information may be obtained on the ACRL Web site:

\section{http://www.ala.org/acrl/awards}

or by contacting Casey Kinson at (312) 280-2511 or ckinson@ala.org

\section{DEADLINE: DECEMBER 7, 2012}

